\title{
Tumor Identifier Test Code
}

National Cancer Institute

\section{Source}

National Cancer Institute. Tumor Identifier Test Code. NCI Thesaurus. Code C117447.

A character or string that represents the short code name of the tumor identification assessment. 